\title{
Open Sores of a Republic: Injustice and Poverty as Motifs in Alex La Guma's First Three Novels
}

\author{
OGBEIDE, O. Victor \\ Department of English and Literary Studies, Faculty of Arts \\ Ekiti State University, Ado-Ekiti, Ekiti State, Nigeria \\ Tel: +23408062159450Ｅ-mail: ogbeide_v@yahoo.com
}

Received: 01-07-2013

Accepted: 02-08-2013

Published: 01-11-2013

doi:10.7575/aiac.ijalel.v.2n.6p.42

\begin{abstract}
This paper examines injustice and poverty as motifs in Alex La Guma's first three novels. A motif is a recurrent formal element in a work of art. The foundation of apartheid is injustice which often leads to massive poverty on the part of the non-white community whose members are hapless victims of marginalization and disfranchisement in the Republic of South Africa. The prevalence of the twin forces of injustice and poverty in apartheid South Africa which La Guma artistically portrays in his first three novels confers on them the status of a motif. This, in itself, is a function of the novelist's deference to realism and artistic relevance. The paper discovers that the unrelenting travesty of justice and the prevalence of destitution which describe so many unsavoury scenes in the novels in focus are due to the non-whites' lack of meaningful political consciousness which itself is a function of the racist government's stamp on oppositional discourse. It is this vacuum that the puny and ineffective pockets of individual acts of courage attempt to fill in the three novels to no avail.
\end{abstract}

Keywords: injustice, poverty, motifs, apartheid, marginalization, realism

\section{Introduction}

In his Poetics, Aristotle defines poetry as an imitation (or mimesis in Greek) of human action. Aristotle's theory of mimesis which was a celebrated defence of poets in the Republic was not the relation of one literary work to another literary work which serves as its model but a re-presentation; the poem imitates "by taking a type of human action and re-presenting it in a new medium, or material - that of words" (M.H. Abrams, 1981:81) Central to Aristotle's spirited defence was the need to view any literary text as a representation of life. In deed, away from the fighting goblins and incestrous gods and goddesses which Plato had harped on, Aristotle's thesis was that any creative enterprise should be seen as an illumination of the socio-historical realities of its enabling societies. It is, therefore, little surprising to note that the emphasis on realism rather than the romance of the earlier period was a basic factor in the rise of the English novel during the early eighteenth century.

Over the years, and in spite of critics' different labels and interpretations of the term, from verisimilitude to naturalism or slice of life, realism has become the touchstone of literary criticism. James Redmond, for example, avers that novelistic excellence should be located only in "a minute fidelity of imitation" (1980:xi) Henry James (1884) is even more authoritative:

The only reason for the existence of a novel is that it does attempt to represent life. When it religuishes this attempt, the same attempt that we see in the canvas of the painter, it will have arrived at a very strange pass (Kaplam, 1957:422)

While acknowledging the formal elements in a literary work, the mimetic critic believes in the indispensability of any works of art's ability to imaginatively capture the realities of its immediate society to justify its existence. "Realism", says Ayo Kehinde (2012:28), "is perhaps the most widely used literary canon that the African critic employs in his evaluation of African literary works". In deed, in Africa, to be realistic is to be committed and socially relevant. Ngugi wa Thiong'O for example, states that literature should reflect the lopsided power structure in Africa and profer its solution to be relevant. In the fifties and sixties, Wole Soyinka had warned his fellow African writers to be more concerned with the signs of uncertainties in the continent rather than occupy themselves with foraging for the socalled cultural gems in the dim past of Africa.

Arguing his case for social realism in the face of the oppressive realities of the former apartheid policy in South Africa, Peter Nazareth (1972:21), had called on the writers in the region to be concerned with

fighting apartheid with demonstrating how monstrous apartheid is, with showing how it dehumanizes everybody.

Peter Nazareth does not mince words in asserting that any realistic and committed writer, especially from South Africa, who fails to portray the obnoxious apartheid system in South Africa and its effects on the non-whites will be guilty of artistic irrelevance. As expected, commitment to reality and political involvement has remained a big feature of the 
South African novel prompting critics like Ogude (1981:9), to state that South African literature is "both history and literature".

As a socially committed writer, all of La Guma's works focus on the apartheid policy and its effects on the lives of the common people who are notably the non-whites, a term that encapsulates the coloured and the black peoples of South Africa. According to him, "all my works are concerned with the contemporary South African scene, particularly the experience of the non-white population" (Vinson, 1976:782). As long as it lasted, apartheid was a virulent cancer that affected every aspect of the South African life. This paper sets out to examine two aspects of the negative effects, namely injustice and poverty in La Guma's A Walk in the Night (1962), And a Threefold Cord (1969) and The Stone Country (1974).

"A motif", says Judith Roof (2005: G-2), "is any significant repetition of images, symbols, language, action or other elements of a literary look". Any idea or theme that recurs in a story is a motif. Motif is a way stories organize images or themes through repetitions. Injustice is a crass violation of justice or a denial of justice. It is a state of inequity, iniquity and grievance. Poverty on the other hand, is a state of being poor or without competent subsistence. It is a state of need and penury. According to the New International Webster's Comprehensive Dictionary of the English Language (2003:986), "synonymns of poverty include beggary, destitution, distress, indigence, pauperism, penury, privation and mendicancy". Unredressed injustice can lead to poverty especially in material terms. Although La Guma by all standards would not be classed among the proletariat of District Six in South Africa, his first hand experience of the harrowing realities of the members of this class who were ravaged by crass injustice and crunching poverty was later to inspire him to expose the situation with a view to changing people's views about what was happening in South Africa. The very foundation of the apartheid regime in South Africa was injustice which in turn engendered massive poverty among the non-whites, especially the blacks who were evacuated from their ancestral land and "herded" into Bantustans all in the name of separate development. La Guma's constant description of scenes of injustice and poverty to the level of motifs in the three novels under study is in deference to his embrace of realism in literary creativity.

\subsection{Theoretical Framework}

Like many concerned South African writers (Can Themba, Lewis Nkosi, Es'kia Mphahlele, Bloke Modisane etc.), La Guma's writing reflects the struggle against apartheid by the marginalized non-whites. This work is, therefore, clearly Marxist in its orientation. According to Terry Eagleton (1976:VII)

Marxism is a scientific theory of human societies and of the practice of transforming them; and what that means rather more correctly, is that the narrative Marxism has to deliver is the story of the struggles of men and women to free themselves from certain forms of exploitation and oppression.

La Guma considers literature as a weapon against apartheid with its travesty of justice. He confessed once that the South Africa situation actually inspired him

to expose the situation with a view to changing people's ideas about what is happening in South Africa so that they can move forward to take down the barriers which exist between different peoples (Nkosi; 1972:IX)

La Guma's ideological persuasion, no doubt, finds a support in Ngugi wa Thiong'O's view that "literature as a creative process and as an end is conditioned by historical, social forces and pressures; it cannot elect to stand above or transcend economics, politics, class, race" (1981:6)

\subsection{A WALK IN THE NIGHT: HUMANITY ON THE RUN AMIDST INJUSTICE AND POVERTY}

In this work, Michael Adonis, a coloured youth, is unjustly sacked from his job at the factory by his white boss for going to ease himself. Blinded by rage at his unmerited sack, Michael later visits his vengeance on an old and decrepit uncle Doughty with whom he lives in the squalid tenement. In the jungle of District Six, South Africa's toughest quarter, injustice often leads to more injustice. This must be the reason for Michael's unpremeditated murder of the old and asthmatic Doughty who is not even remotely connected with his problem. Willieboy is unfortunately arrested and tortured to death for this offence.

The unsavoury effects of the manichean bifurcation imposed by apartheid on the blacks and coloured (racially mixed people) are evident in the way injustice and poverty dog their unenviable life. First published in 1962 and later in 1967, A Walk in the Night marks La Guma's transition from short stories to full length novel. Often referred to as a novella on account of its small volume, $A$ Walk in the Night, says Ntaganira (2005:17), was written by La Guma "as part of his contribution to ending apartheid injustices".

It is the duty of the police all over the world, to protect people and their property. In apartheid South Africa however, this is hardly the case as they are a part of the oppressive regime. In deed, according to La Guma, "in South Africa, we live with the police. I believe black people are constantly being harassed by the police... so that when one is concerned with social situation one cannot leave the police" (Abrahams, 1991:23). The brutal, merciless and ubiquitous South African police with "frozen and hard faces, with desperate eyes and voices the equivalent of the snap of a steel spring" (11), are hardly friends of the non-white South African. Their monstrous mien belie their supposed friendly disposition. To them, the non-white youth is first a criminal before he is proven otherwise. It is the unjust search of his person by the police that later infuriates Michael the more, making him to commit murder. 
In the vast recesses of Michael's remorsefulness, he even contemplates giving himself up to the police. But in an apartheid South Africa, where the police "pray for something to happen" so that they can have an alibi for arresting and brutalizing the non-white youth, can he actualize this thought? Hear him:

May be I ought to go and tell them (police). Bedonerd. You know what the laws will do to you. They don't have any shit from us brown people. They'll hang you, as true as God, Christ, we all got hanged long ago. What's the law for? To kick us poor brown bastards around. You think they're going to listen to your story? Jesus, and he was a white man too!.... Ja, stay alive and get kicked under the arse until you're finished too. Like they did to your job (44).

We are forced to sympathize with Mikey in his inner turmoil because we realize that he will never get justice from the system. According to Adrian Roscoe (1977:236), "we are bewildered in our moral response as Michael himself. Clear moral choices under apartheid become as hard as everything else"

The greatest injustice in the novella is the cold blooded murder of the innocent Willieboy by the trigger-happy constable Raalt and Andries. In their prejudiced hatred of every black youth, Willieboy is not given a chance to defend himself before he is killed. In his character analysis, Anders Breidlid (2002:143) states what he calls "the positional superiority of the white officer (as represented by the apartheid police) over the positional inferiority of the non-whites" which is due to the apartheid policy of the South African regime. This submission is substantiated by the case of the two white policemen who unjustly hunt and cause the death of the innocent coloured boy, Willieboy, "for the perceived murder of Doughty, the old white man inhabiting District Six" (Breidlid 2002:143). The racist policemen are only interested in the murder of Uncle Doughty because he is a white man, his status as a slum dweller notwithstanding.

Everywhere he goes, constable Raalt is haunted by his wife's alleged marital unfaithfulness. Rather than confront his wife, the brooding constable takes solace in the unjust brutality of every black youth as his tension valve. Even then, constable Raalt is not alone in this transfer of aggression to the hapless and helpless blacks as virtually every policeman in the Republic seems to find uncanny pleasure and emotional outlet for his frustration by the obnoxious regime in punching the non-white youth.

The naked injustice in District Six is complemented by poverty which seems to be the lot of every resident there. Michael Adonis, for example, is a walking definition of privation. La Guma's pejorative description of him is embarrassingly revealing.

The young man wore jeans that had been washed several times and which were now left with a pale-blue colour flecked with old grease stains and the newer darker ones of that day's work... The jeans had brass buttons and the legs were too long so that they had to be turned up six inches at the bottom. He also wore an old khaki shirt and over it a rubbed and scuffed and worn leather coat with slanting pockets and woolen wrists. His shoes were of the moccasin type with leather tongs sticking the saddle to the rest of the uppers. They had been a bright tan once, but now they were worn a dark, beginning to crack in the grooves across the in-steps. The thongs, had broken in two places on one shoe and in one place on the other (2)

As the depressed Mikey climbs to his room in a dilapidated tenement block, La Guma shows us the rot, neglect, filth, smells and squalor which describe the non-white abode in South Africa.

The stair case was worn and blackened, the old banister loose and scarred. Naked bulbs wherever the light sockets were in working order cast a pallid glare over parts of the interior, lighting up the big patches of damp and mildew, and the maps of denuded sections on the walls. Some-where upstairs a radio... A baby wailed with the tortured sound of gripe and malnutrition... (23).

If Mikey's position is pathetic, that of the enigmatic Joe is even worse Joe's destitution is so bad that he now depends on dead and stinking starfish on the beach for survival. Even so, the oppressive system has denied him of his siblings and parents. Like a lone ranger that he is, Joe's only true relief from the urban squalor around him seems to be the shore where he hopes to ponder calmly the still sad music of the oppressed humanity of South Africa. The mendicancy of the Lorenzos is announced to the world by the decay, grime cobwebs, bacteria and sundry coackroaches that seem to stalk every corner of their one room shack. In the fetal heat and slippery dampness of the Lorenzo's room dwell vectors of all kinds of diseases namely maggots, insects, vermins and spiders with death either in their minute feet or in their suckers. In this death hole of a room live Mr. Lorenzo and wife Grace with their five children. While it is unjust for the cruel regime to have driven the entire family into such a penurious state on account of its anti-black people policies which are no doubt responsible for Lorenzo's inability to get a good job to enable him cater for his own family, it is equally injust for the "right" conscious Lorenzo to think only of his pleasure every night without bothering about the consequence pregnancy. For the couple to have brought children into the world they can hardly cater for is perhaps, one of the greatest injustices in the novel. This is because it is tantamount to visiting violence on the innocent children who did not ask to be born in the first place. 


\subsection{AND A THREE FOLD CORD: WHEN HUMANITY GROVELS IN THE MUD OF DESTITUTION}

Set in the cape, And a Threefold Cord not only records the "here and now" of the cape flats but indeed, shows La Guma as he creatively "paints a very bleak picture of the socio-economic condition under apartheid" (Anders Breidlid, 2002:78) This bleak picture is manifested in the extreme poverty of the Pauls family, a veritable microcosm of the nonwhite families in Cape Town District Six where the dire consequences of apartheid's repressive laws are experienced daily.

Written in 1964, in And a Threefold Cord, La Guma plays the role of a social historian. According to Abrahams (1985:70), La Guma wrote this novel because he

was interested in recording the life of a community under various conditions. He thought it would help to bring to the reader an idea of what goes on in the various black areas of the cape and that through a novel, this could be done.

The Pauls family live on the edge of Cape Town where there is no electricity, inside taps, good drainage and where the people have to endure daily mud splashes either on their way to, or from job when they are lucky to have one. The daily battle to repair leaky roofs and keeps away the elements is often taken for granted. In spite of the novel's central thesis on solidarity it is abject poverty that seems to unite members of the Pauls' family and friends. La Guma shows us Dad Pauls whose failing health has become a big concern in the penurious family as "a sick old man clinging with brittle nails to the tortuous cliff of life, holding on with a last desperate effort" (34). Now a pathetic equivalent of a child's drawing of a man with his face clawed by sickness and want, Dad Pauls' physical deterioration is a function of the racist-inspired abject neglect and poverty. Members of Dad Pauls' family are so indigent that they cannot afford to send him to a hospital for better treatment. Apart from Charlie who manages a menial job, virtually all the other members of the family are jobless. Jorny boy is a scavenger at the rubbish heap. The eccentric and wild Ronny simply wanders about the tenement with a criminal intention that eventually finds its fulfillment in the murder of Susie Meyer. Totally stripped of all noble traits, the perenially drunk Ria blends her degraded state with the all pervading squalor and decay of her surroundings. La Guma shows us her picture, which is now nothing but a squalid parody of a female:

Her hair straggled like wet and dirty straw, her clothes reeking of wine and vomit and she cursed and wept and laughed about her in a voice as harsh as a death rattle (54)

Uncle Ben lives in a little shack in the impoverished settlement "drinking away most of the little money he earned doing odd home painting jobs" (77) Like a veritable definition of penury, Uncle Ben is always dressed in holed jersey, worn and patched trousers with cracked and muddy shoes. In deed, from Charlie in his "soiled underwear" and faded jeans to the muddy feet and ageless layabouts whom La Guma describes as a motley collection of scarecrows, dummies stuffed with poverty" (40), are poverty-stricken non-whites who are the very equivalent of the dregs of humanity from the crime and disease-ridden District Six of South Africa.

A unique feature of the narrative is the correlation between characters and the environment which is held together with the image of filth and unbelievable decline of the entire suburban culture. Poverty-stricken characters are skillfully linked to their degraded tumble down, sterile and decadent shanties and pondokkies in the Cape Flats. La Guma, for example, presents a striking relationship between the decrepitude of the inhabitants and the squalor of their environment as seen in one of the streets.

...it was the corpse of a street that died a long time ago choaked to death by
neglect and left to be nudged and toed by the surrounding hovels which lay on its
crumbling flanks like hyenas waiting to devour it. A few old bricks and plaster
houses still stood or rather tottered at the intervals along the mired street. Most of
their windows had gone and cardboard boxwood or stuffed rugs gave the
impression of rough patches over gaping eye sockets. Paint and plaster had fallen
from the walls leaving raw wounds of brickwork and roof were held down with
rows of boulders (98)

Considering the pejoristic description of a typical street in the shanties above, one is little surprised at the inhabitants who, in their different stages of disintegration, are not only "weighed down by burden of racial oppression and limitations arising from various oppressive laws (but) also stand out as pathetic victims of actual pathological ailments' (Asein, 1984:91). What confronts the reader in the lavish repulsive details of La Guma's leprous prose is a filthy environment that is riddled with the smell of rain mixed with the general smell of the settlement that is "fused into a pervading perfume of bitter dereliction" (101). This is, however, a striking contrast to the affluent and indifferent community of the whites where roads are laid out with night traffic sweeping by and "rubber skimming over stippled surface sounding like sprayed water" (87) The rooms in the warping and cracking house of the Pauls which groans like a prisoner on the rack are not only leaky in countless number of places but also full of all kinds of irritating smell. The presence of a battered cracked mirrored loose-hinged wardrobe completes the family's abject poverty and neglect.

Roman with his ill clad, malnourished and potbellied children and wife lives in what looks like an amalgamation of a kennel, a chicken coop and a lean-to shed. Economically strangled, George Mostert, the white station owner, like Uncle Doughty in $A$ Walk in the Night is now an inconsequential non-entity whose wife has since run away with another man. The rabidly racist but now wrecked Mostert's case, according to Asein (1986:80), is a clear case of 
the problem of existence which confronts men, be he white, coloured or black in a material culture where the essence of the individual is dependent on the material acquisition that lies under his control.

The sorry spatial constraints under which the Pauls live is so pathetic that privacy and possible solitary reflection are blocked. Even then, this restricted physical space is not free from nightly raids by the apartheid police whose crudeness and injustice begin with no respect for private space and end with a denial of human dignity and personhood. Witness, for example, how they unjustifiably force their way into Charlie and Freda's place while they are asleep and their crude abuse:

The sergeant sneered at the woman (Freda). 'Blerry black whore'... He (Charlie) said, frowning, Hell, what you crying for' they didn't do something, did they?...

'he said I was a whore' (88).

\subsection{THE STONE COUNTRY: HUMANITY BEHIND BARS}

In The Stone Country, George Adams and his friend Jefferson are arrested by the apartheid police for distributing antiapartheid leaflets. They are imprisoned with hardened criminals who fight one another for supremacy even in their incarceration. The novel ends with the attempt by some of the prisoners to break jail.

If the impoverished non-white family is at least allowed to grovel in the mud of privation in And a Threefold Cord, in The Stone Country, it is entrapped in prison by the unjust system. Here, the prison setting with its rapists, robbers, alcoholics and murderers become an extended metaphor in which the Cape Town jail and the Republic of South Africa are seen as one. The prison guards take over the functions of the regular political police in this microcosmic South Africa. Most of the prisoners have been imprisoned on flimsy grounds from loitering, lack of permit to distribution of "illegal" pamphlets. Through George Adams, the central character in the work, La Guma shows us the high handedness, insensitivity and injustice that rule the prison. His first day in the prison witnesses the slaps and shoves with which the prison guards urge the prisoners to answer their names. The prisoners are made to strip stark naked before receiving their convict uniform. They cannot even take their bath because to do so would mean unwanted overtime for the guards:

Jesus, I am not going to wait. Going now,... These bastards can wash in the morning, to hell with it. I'm not working blerry overtime (27).

The guard's bitter and sarcastic swipes meant to brutalize Adams and his friend Jefferson psychologically in order to lower their morale notwithstanding, the two friends are further kept in separate cells without trial in the Cape Town prison. In spite of the fact that he is a political prisoner, George Adams is specifically kept in the same cell with other hardened hoodlums like Yusef The Turk, Casbah Kid, Butcher boy Williams and Folly. For talking back to the prison guard Fatso, and playing with a cat in the prison, George Adams is made to forego his meals for three days. He is to be transferred to the Isolation Block, where he is expected to pine away in silence. The episode involving the cat and the mouse in the prison is not only a re-enactment of the deadly conflict between the blacks and the agents of the larger society but also a symbol of what the obnoxious apartheid rule stands for in South Africa. In the words of Umukoro (1982:7)

the mouse symbolizes the blacks who, inspite of their militating inadequacies, duck and dodge to avoid the claws and fangs of white minority rule.

Apart from the unjust physical brutality and psychological torture, the prison guards deliberately mass together the prisoners to cause disaffection and infighting which, in the final analysis, detract their attention from their common enemy:

with over forty prisoners locked up in the middle of summer, the smell of sweat was heavy and cloying as the bodies of the men, like layers of cotton wool, like a thick sauce which moistened a human salad of accused petty thieves, gangsters, rapists, burglers, thugs, brawlers, dope peddlers .... sucking hopelessly at the bitter disintegrating butt end of life (80).

The wider implication of the above can be seen in the do-or-die battle for supremacy in the cell between Butcherboy and Yusef the Turk. It is a dog-eat-dog system that defines the tragic reality of life in South Africa where many of the so-called prisoners are there in the first place courtesy of the injustice and poverty created by the oppressive system. But how are the oppressed non-whites themselves reacting to the blatant injustice and massive poverty in the society?

\subsection{RESPONSES TO INJUSTICE AND POVERTY}

Violence, criminality and protest are the non-whites' responses to the unwarranted injustice and poverty which have marginalized their life in the Republic. Blinded by rage arising from his unjust sack by his white boss in $A$ Walk in the Night, Michael Adonis is further driven to nuts by the police officer's search of his person. Injustice often begets injustice, Mikey later venges his spleen on Uncle Doughty who, like himself, is a victim of the oppressive system. That the violence on the old man is unpremeditated and gratuitous is seen in Mikey's regret later that he "didn't mean to kill the Blerry old man" (29). The frustrating circumstance has awaken the atavistic instinct of violence in Michael and the innocent old man is the loser for it. Although convicted, unfortunately, for the murder of Doughty and dies for it, Willieboy is nevertheless a criminal in his own right. Willieboy does not work to earn his living because to him, "whether you work or don't, you live anyway, somehow" (18). In an attempt to soften the hard edges of humiliation and degradation, many of the young persons resort to cheap sex and the smoking of "dagga". Still, others seek solace in 
drinking pubs where James Mathews (1979:146) says "menfolk, castrated by degradation, seek their manhood in a jug of wine as brackish as their bile". A pervading sense of lawlessness seems to unite the many social derelicts who do not feel bound by the punitive laws of the white man. Foxy, a member of the group of hooligans, tells Michael with pride, for example, that they don't care about the law.

With a possible exception of Adams and Jefferson, all the characters in The Stone Country are violent. Butcherboy is presented as a depraved monster who rules the cell. Yusef the Turk, a genius in self defence, is as dangerous as a knife blade. Casbah Kid is doomed to hang and follow both parents in a violent death for committing murder. The frustration of all the dangerous characters in the cell finds expression in different criminal activities ranging from smoking, fighting, escaping, murdering to writing on the prison walls. To Casbah Kid, the inevitability of violence in a place like South Africa where injustice and destitution hold sway is beyond debate. He has even gone fatalistic about it as he tells the bewildered George Adams. Throughout the novel, all the imprisoned characters are prepared to practise their violence even in prison. Like injustice, violence begets violence. The injustice of the system and the brutality of the police have hardened the wretched non-whites into violence. Frustrated by the fact that a black man is not even free to be by himself in the Republic of South Africa, Charlie in And a Threefold Cord hits one of the policemen on his exposed jawbone. Frantz Fanon (1980:25) is right:

the police is the bringer of violence into the home and into the mind of the native

in a colonial context because it imposes a dichotomy upon the people... the

Europeans versus the natives.

Roman's poverty has made him a piece of danger even to his own family. Jobless and so unable to feed his eleven children who have become a veritable definition of kwashiorkor, Roman often takes to petty thieving; and when there is nothing to steal, he beats his wife as the cause of his troubles. Bombarded by Dad Pauls' sickness and the poverty in the family, Ma Pauls finds escape in religion, clinging to her Bible in a fetishistic manner. Uncle Ben has found salvation of a sort in cheap wine which he drinks until he is drunk. The perennially drunk Ria is a study in degraded humanity. Like Miss Nzuba, she is used by La Guma to show the dehumanizing impact of the apartheid machine. Jorny boy has turned to scratching around the rubbish heaps with other children in the neighbourhood. Thus, stripped off their cultural props by the oppressive system, La Guma's non-white characters disintegrate like Kurtz in Conrad's Hearts of Darkness. To the degradation, injustice and poverty that the system imposes on them, they reply in kind. Indeed, as JanMohamed (1982:279), has rightly observed, "to apartheid's exclusivist legal and economic policies they can only reply with crime and theft. La Guma does not allow his characters or narrative to transcend the terms defined by apartheid".

\section{Conclusion}

La Guma's three novels explore the coloured community's experience of apartheid-induced injustice, deprivation, alienation, poverty and marginalization. All the characters depicted in these three novels find themselves at the mercy of an authoritarian society and oppressive system whose foundation is injustice. In all these novels, La Guma makes the experiences of these characters available to the reader through a careful and detailed description of specific and concrete immediacy. In the words of JanMohamed (1982:281).

rarely does he discuss poverty or lack of freedom in abstract terms nor does he spend much time in articulating the consciousness of his character. He confines himself to placid and factual description of concrete human behaviour and the material surface of society.

All the poverty-stricken characters in these three novels are presented as politically unaware. They all seem to have succumbed to what Cormaroff and Cormaroff (1981:18), calls "colonization of consciousness". This is why they seem condemned to suffer the fate of a people without initiative or resources. What prevails in these novels are occasional individual acts of courage which are not only often misguided and ineffective but puny. For example, the punching of the policeman in And a Threefold Cord by Charlie, according to Anders Breidlid (2002:21).

$\ldots$ is a temporary relief to Charlie; some of his pent-up anger is liberated through the punch but, as Baluntansky correctly observes, it provides him with no real victory.

This lack of political consciousness by the non-white characters is no doubt a worrisome issue in La Guma's first three novels. La Guma himself tells us about his first novel:

One of the reasons why I called the book $A$ Walk in the Night was that in my mind the coloured community was still discovering themselves in relation to the general struggle against racism in South Africa. They were walking, enduring and in this way they were experiencing this walking in the night until such time as they found themselves and were prepared to be citizens of a society to which they wanted to make a contribution. I tried to create a picture of a people struggling to see the light, to see the dawn, to see something new other than their experiences in this confined country (Abrahams, 1955:49)

It is in view of the above in which La Guma sees himself as carrying out a kind of artistic social responsibility that Pointer (2001:213) appreciates $A$ Walk in the Night as a novella that "brought information in literary form about the injustices of apartheid to a wider audience". La Guma was later to extend this boundary of social responsibility by 
investing his characters with some political consciousness. In The Stone Country, George Adams and Jefferson are arrested by the government for distributing anti-government leaflets. Towards the end of And a Threefold Cord, Charlie and Aunt Mina are presented as having acquired some sense of consciousness of colonization. Through these characters' defiance of the regime's stamp on oppositional discourse, La Guma emphasizes that the much cherished solidarity in the work must be backed by political consciousness as a huge bulwark against the oppressive system. Although it is still theoretical here, its praxis is later to come full blown in La Guma's In the Fogs of the Season's End (1972) and Time of the Butcherbird (1979) where the twin forces of injustice and poverty are finally confronted revolutionarily.

In his Noble Prize Lecture, the Russian novelist, Solzhenitsyn (1970:29) states that, "Art recreates in flesh experiences that have been lived by other men, and enables people to absorb them as if they were their own". Through La Guma's first three novels, we are not only exposed to the injustice and poverty that became the unenviable lot of the non-whites in the heyday of apartheid; we actually feel them.

\section{References}

Abrahams, C. (1985) Alex La Guma. Boston; Twayne.

Abrams M.H. (1981) A Glossary of Literary Terms. New York: Holt, Rinehart and Winston.

Asein, S.O. (1987) Alex La Guma. The Man and His Works. Ibadan: New Horn in Association with Heinemann Educational Books Ltd..

Breidlid, A. (2002) Resistance and Consciousness in Kenya and South Africa Subalternity and Representation in the Novels of Ngugi wa Thiong'O and Alex La Guma. Frankfurt: Peter Lang.

Cormaroff, Jean and Cormaroff John. (1991) Of Revelation and Revolution: Christianity, Colonialism and Consciousness in South Africa. Chicago: University of Chicago Press.

Eagleton, T. (1976) Marxism and Literary Criticism. London: Mcthuen.

Fanon, F. (1968) The Wretched of the Earth. New York: Grove Press.

Field, R.M. (2001) Alex La Guma: A Literary and Political Biography of the South African Years. Being an unpublished D. Litt. Thesis. Western Cape, The University of Western Cape.

James, H. (1957) "The Art of Fiction; (1884)" in Charles Kaplan (Ed) Criticism. Twenty Main Statements. San Francisco: Chandler Publishing Company.

JanMohamed, A.R. (1982-3) "Alex La Guma: The Literary and Political Functions of Marginality in the Colonial Situation". Boundary 2 11, Nos 1-2 (Fall-Winter) 271-290.

Kehinde, A. (2012) "The Socio-Historical Context(s) of Twentieth Century Anglophone Novels" in Papers in English and Linguistics Volume 13, 25-49.

La Guma, A. (1962) A Walk in the Night and Other Stories. Ibadan: Heinemann.

(1969) And a Threefold Cord. Berlin; Seven Seas Publishers.

(1974) The Stone Country. London: Heinemann Educational Books Ltd.

Matthews, J. Rowland Smith (1976) (Ed) Exile and Tradition. London: Longman and Dalhousie University Press.

Nazareth, P. (1972) Literature in Society in Modern Africa. Nairobi: East African Literature Bureau.

Nkosi, L. (1981) Tasks and Masks: Themes and Styles of African Literature. Harlow, Essex: Longman.

Ntaganira, V. (2005) “Alex La Guma's Short Stories in Relation to A Walk in the Night: A Socio-Political and Literary Analysis” Being a Minithesis Submitted to the Department of English, University of the Western Cape.

Ogude, S. (1991) “African Literature and the Burden of History: Some Reflections”. Ernest Emenyonu (Ed) African Literature and African Historical Experience. Ibadan: Heinemann, 1-9.

Pointer, F. A. (2001) Passion to Liberate. La Guma's South African Images of District Six. Trenton: African World Press.

Redmond J. (1980) (Ed) "Editors Preface” Drama and Mimesis. Cambridge; Cambridge University Press, XI-XIX.

Roof, J. (2005) Understanding Fiction. Boston: Houghton Miflin Company.

Roscoe, A. (1977) Uhuru's Fire. African Literature: East to South Africa. Cambridge: Cambridge University Press.

Solzhenitsyn, A. (1970) Noble Prize Lecture. London; Stenvalley Press.

Vinson. J. (1976) (Ed) Contemporary Novelists (2nd Edition). London: St. James Press Ltd.

Wa Thiong'O, N. (1981) The Writer in Modern Africa. London: Heinemann. 